\title{
Chemical and Physical Process Combinations: Microwave in Lignin Degradation of Pecan Shells as Alternative Fuel Raw Materials
}

\author{
Rini Kartika Dewi \\ Chemical Engineering Department \\ ITN Malang \\ Malang, Indonesia \\ rinikd@yahoo.co.id \\ Safarina Tsulusia \\ Chemical Engineering Department \\ ITN Malang \\ Malang, Indonesia \\ rinikd@yahoo.co.id
}

\author{
M. Istnaeny Hudha \\ Chemical Engineering Department \\ ITN Malang \\ Malang, Indonesia
}

\author{
Anindita Rauda \\ Chemical Engineering Department \\ ITN Malang \\ Malang, Indonesia
}

\begin{abstract}
Pecan shell is an abundant amount of biomass waste and has the potential as one of the fuels, with a very hard texture and having holocellulose content of $\mathbf{4 9 . 2 2 \%}$ and lignin $54.46 \%$. Whereas the pecan shell composition after in the form of 100 mesh powder was $33 \%$ hemicellulose, $17 \%$ cellulose and $34 \%$ lignin. In order to be used as an alternative fuel, one of the initial stages that needs to be carried out is through the process of degradation of lignin or the delignification of components present in pecan shells.

The process of concentration and microwave process time at microwave power 440 Watts was successfully degraded through a combination of chemical and physical processes with variables of $\mathrm{NaOH}$. The $\mathrm{NaOH}$ concentrations used were $1 \mathrm{~N}$, $2 \mathrm{~N}$, and $3 \mathrm{~N}$ while the delignification times were $5,10,15,20$, and 25 minutes.

From the analysis with the Chesson method, the lowest lignin levels reached $6 \%$ at $2 \mathrm{~N} \mathrm{NaOH}$ concentration and 20 minutes process time. With the data generated, it can be concluded that the process of combination of chemistry and physics can reduce lignin levels in pecan shell powder by $82.35 \%$
\end{abstract}

Keywords-Delignification, $\mathrm{NaOH}$-Microwave, Cellulose, Hemicellulose, lignin

\section{INTRODUCTION}

The increasing need for renewable energy to meet the lifestyle of today's society makes the competition for food and energy from biomass a trending topic in all parts of the world today, as an alternative energy raw material given the declining fossil energy needs, this makes researchers continue to research and develop biomass materials that can be used to replace it. One of the biomass that can be used as alternative materials is candlenut shells, the quantity of which is very abundant in Indonesia. The composition of the candlenut shell consists of $49.22 \%$ holocellulose and $54.46 \%$ lignin [1]. From the content of the candlenut shell has the potential as a renewable fuel both used as liquid fuel (bioethanol) and solid fuel.

Pecan shell raw material when converted into fuel belongs to the second generation group, which to produce liquid fuels must pass through four important stages namely pre-treatment, hydrolysis, fermentation, and ethanol purification. Pre-treatment is needed to break down the size and structure of material that are still macroscopic and microscopic from a biomass into microscopic compositions and chemical components simple one and get more yields [2]. The purpose of pre-treatment is to open the structure of lignocellulose so that cellulose becomes more accessible by enzymes that break down polysaccharide polymers into sugar monomers. Lignin can be an inhibitor of the hydrolysis process because it will inhibit the activity of enzymes in yeast in the conversion of simple sugars into ethanol [3]. Therefore the pre-treatment process plays an important role in bioethanol production. This pre-treatment is also called delignification. Delignification aims to reduce the levels of lignin in lignocellulosic material. This delignification process will dissolve the lignin content in the material so as to facilitate the process of separating lignin from fiber. The pretreatment process by using $\mathrm{NaOH}$ has been shown to eliminate the lignin component (delignification) and can increase the porosity of the cellulose component and is one of the effective and inexpensive methods [4]. In some studies, delignification generally uses $\mathrm{NaOH}$. In his research on bagging delignification was using $\mathrm{NaOH}$ delignificator $2 \%, 4 \%$ and $6 \%$. The results showed the most reductions in lignin were obtained through the use of $6 \% \mathrm{NaOH}$ which was $32 \%$, from $17.65 \%$ to $11.9 \%$ ). [5]. Whereas previous studies using candlenut shells obtained $76 \%$ cellulose content at $15 \%$ $\mathrm{NaOH}$ concentration, $\mathrm{KOH}$ alkali type with a concentration of $15 \%$ with a value of $77.67 \%$, and with a $\mathrm{Ca}(\mathrm{OH}) 2$ alkaline pretreatment type obtained at a concentration of $15 \%$ with a value of $65,33 \%$. [6]

Delignification research by physical-chemical method is still rarely done, Maharani did delignification with $0.5 \mathrm{M}$ $\mathrm{NaOH}$ solution and 950 Watt microwave power on kepok banana stems yielding cellulose yield $27.265 \%$ and lignin $3.26 \%$ [7] While Sari did delignification on corncobs using corncobs $\mathrm{NaOH} 2 \mathrm{~N}$ and a 40 minute microwave produce cellulose at $69.937 \%$ and lignin decreases to $9,006 \%$. [8] 
According to many researchers the combination of chemical and microwave pretreatments from various raw materials results in higher cellulose and alkaline solutions eliminating lignin. In addition, all previous research has done a lot of processing time for 1 hour, so we also use processing time as another research variable. The delignification of pecan shells is still rarely studied and researchers who have already been namely Dewi have not yet produced maximum cellulose levels or decreased levels of lignin so research needs to be done with the addition of appropriate variations to get optimal cellulose levels. [6]

From these problems the researchers tried to combine the decomposition of lignin through chemical and physical processes Microwave with 440 Watts power and the addition of $\mathrm{NaOH}$ to the candlenut shell.

\section{MATERIALS AND METHODS}

\section{A. Material delignfication process}

Candlenut Shell powder obtained from the size reduction process of the Candlenut Shell with a size of 100 mesh, $\mathrm{NaOH}$ with concentrations of $1 \mathrm{~N}, 2 \mathrm{~N}$ and $3 \mathrm{~N}$ and acetic acid used for neutralization

\section{B. Material preparation}

In the early stages the candlenut shell is cleaned first from impurities which is followed then after cleansing the candlenut shell is dried in an oven at $105^{\circ} \mathrm{C}$ for 24 hours to remove the water content in the candlenut shell. After being dried the pecan shell is crushed with a disc mill until it becomes \pm 100 mesh size powder.

\section{Delignification process}

Weighing as much as 3 grams of hazelnut powder is put into the beaker glass, adding a pre-treatment solution $(\mathrm{NaOH})$ with a concentration according to a variable with a volume of $30 \mathrm{ml}$. Comparison of candlenut shell powder with a type of $\mathrm{NaOH}$ solution is 1: 10. Inserting into the microwave with a time variation $(5,10,15,20$, and 25 minutes), the microwave power used is 440 Watts. After that the sample is neutralized with acetic acid to neutral $\mathrm{pH}$. Lighten again using the oven with a temperature of $105^{\circ} \mathrm{C}$ for 12 hours. And finally the analysis of lignin, cellulose and hemicellulose was carried out by the Chesson Method.

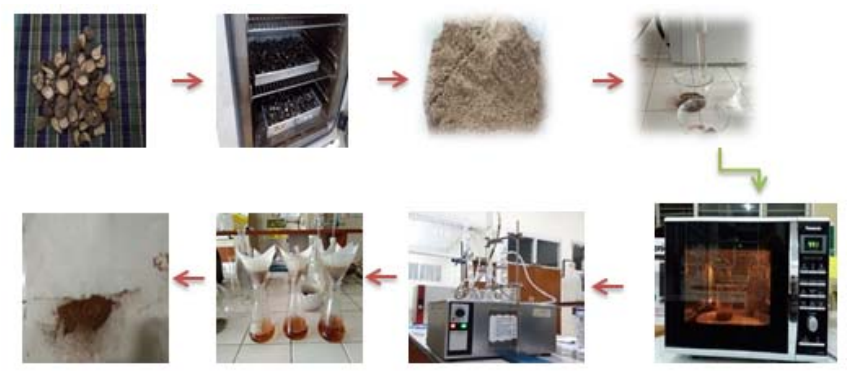

Fig. 1. Lignin Delignification Process From Pecan Shells

\section{RESULTS OF RESEARCH AND DISCUSSION}

\section{A. Delignification of physics (destruction)}

Analyzing pecan shells powder with a size 100 mesh. From the analysis results obtained hemicellulose content of $33 \%$, cellulose content of $17 \%$ and lignin content of $34 \%$. While from the literature found in the early candlenut shells it has a lignin content of around $54 \%$ and $49.22 \%$ holoselulose. From the results of the initial treatment or physical pre treatment can reduce lignin levels as much as $38.18 \%$. Because by changing the size can cause a lignin structure that is separated or detached.

However, the content of each lignocellulose compound depends on each raw material used.
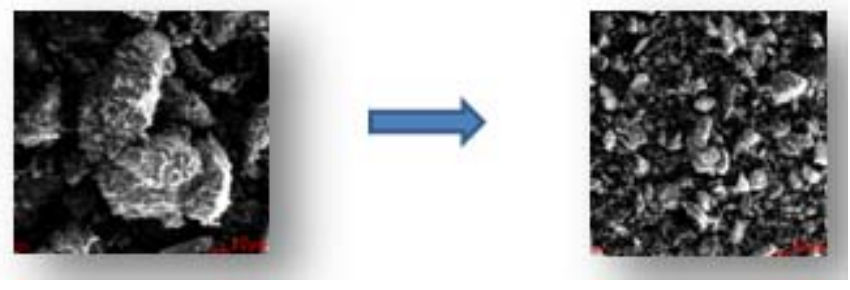

Fig. 2. Pecan Shell Structure with Sem-Edax

Scanning Electron Microscopy (SEM) With Energy Dispersive X-Ray Analysis (Edx or EDA) is also used provide elemental identification and quantitative compositional information. EDAX is a leading provider of innovative materials characterization systems encompassing Energy Dispersive Spectroscopy (EDS), Electron Backscatter Diffraction (EBSD), Wavelength Dispersive Spectrometry (WDS), Micro X-ray Fluorescence (Micro$\mathrm{XRF}$ ), and X-ray Metrology.

Based on Sun \& Cheng's theory (2002) there are several factors that influence the physical delignification process, one of which is the sample size. The size of the sample can affect porosity which then affects the contact with the delignificator. [9] In addition, decreasing the sample size will break the long polymer chain into a shorter polymer chain making it easier to separate lignin from cellulose bonds [10].

According to Maharani (2015) in his research using kepok banana stems, the initial treatment (physical destruction) made the size of the material 100 mesh has a cellulose content of $31.89 \%$ hemicellulose $24.17 \%$ and lignin 6.845\% [7]. Whereas in Permatasari research (2011), bamboo was crushed into 100 mesh powder and lignin was obtained at $9.13 \%$ [11]. In the study of pineapple leaves by Novia, making 100 mesh pineapple leaf powder contains $28 \%$ cellulose content and $3.392 \%$ lignin. [12]

\section{B. Delignification Results Analysis (Lignin Degradation Process)}

From the above explanation it can be said that the candlenut shell through the initial treatment process or the physical delignification process (destruction of the material) 
can cause the breaking of the lignocellulose polymer chain which was originally long to be shorter. The next stage is candlenut shell powder, dissolved with $\mathrm{NaOH}$ will react chemically then put in a microwave to continue the chemical-physical delignification process.

The mechanism of lignin degradation is initiated by the attack of $\mathrm{H}$ atoms bound to the phenolic $\mathrm{OH}$ group by hydroxide $(\mathrm{OH})$ ions from $\mathrm{NaOH}$ [13]. The hydroxyl group in phenol is difficult to decide due to the shifting or movement of electrons due to the double binding bond next to it, so that phenol is only able to release hydrogen atoms in the hydroxyl grouo instead of $\mathrm{OH}^{-}$.

$\mathrm{H}$ atoms in that part are acidic because they are bound to atom $\mathrm{O}$ which has a large electronegativity. The more electronegative $\mathrm{O}$ atom will attract electrons on the $\mathrm{H}$ atom, so that the $\mathrm{H}$ atom will be positively partially charged and easily separated into $\mathrm{H}^{+}$ions. Acidity is also affected by the resonance effect of the alkyl group in the para position, so that the $\mathrm{H}$ atom in the phenolic group will be more acidic. The hydroxide $\left(\mathrm{OH}^{-}\right)$ion from $\mathrm{NaOH}$ will also break bonds from the basic structure of lignin while the sodium ion $\left(\mathrm{Na}^{+}\right)$ will bind to lignin to form sodium phenolate. This phenolic salt is easily soluble in distilled water [14]. The lignin phenolic hydroxyl group is ionized to form its salt and is polar so that the phenolic salt dissolves easily in water. The energy of electromagnetic waves and also the heat generated by microwaves, causes the ease of lignin as the outer layer to be degraded. In addition, the reaction with $\mathrm{NaOH}$ also accelerates this degradation process. Microwaves are expected to help accelerate the breakdown of $\mathrm{H}^{+}$groups that bind to $\mathrm{OH}^{-}$and then form phenolic salts so that from these two physics-chemical processes, the lignocellulose polymer chains will quickly decompose. Next, the lignin chain will separate.

Furthermore, the lignin chain will separate from the lignocellulose chain bonds by dissolving in water or distilled water. This is why in the analysis process reflux is done using distilled water. In addition, washing is also done for several times using warm water. In this process lignin which contains phenolic salts or other hydrophilic groups will dissolve with water and leave cellulose compounds and some hemicellulose.

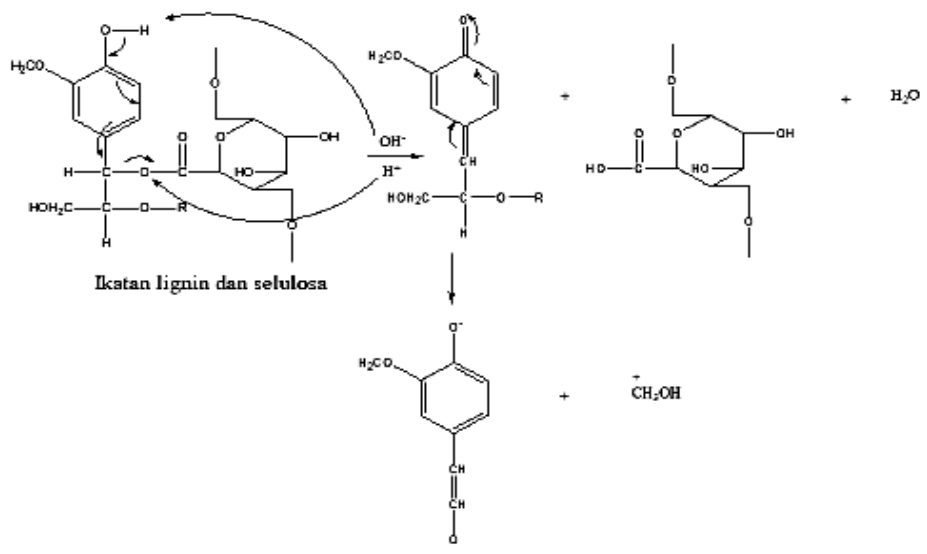

Fig. 3. Mechanism of Termination of Bonds between Lignin and Cellulose by Nucleophils $\mathrm{OH}$

Chemical and physical pre-treatment can reduce levels of lignin and increase cellulose levels better than just physically or chemically. Candlenut shells as we know are very hard so that they will automatically contain more lignin, unlike other biomass wastes (such as rice straw, bagasse, banana fronds, etc. Delignification in microwaves using microwaves aims to break down the complex lignin structure into simpler constituent structures.

TABLE I. TABLE OF EFFECTS OF DELIGNIFICATION TIME AND NAOH CONCENTRATION ON LIGNIN CONTENT

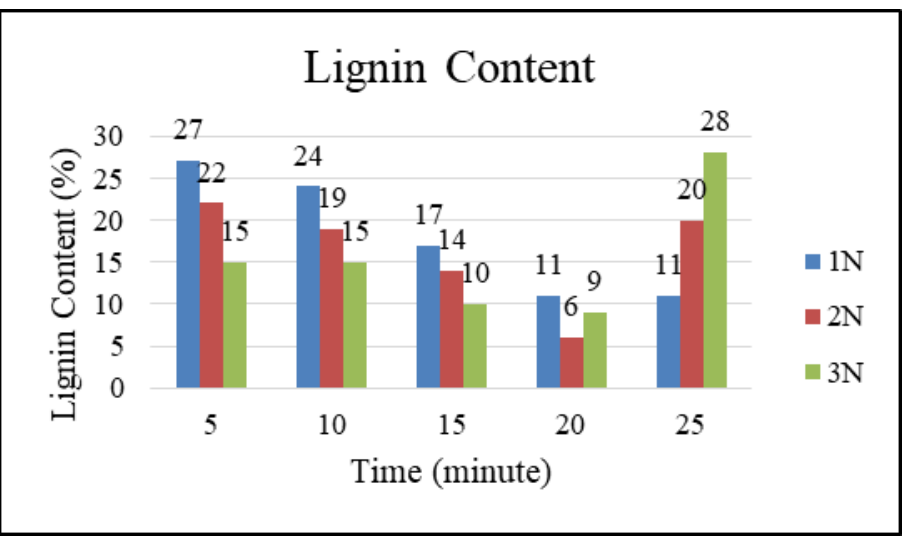

As in Table 3.1 it was found that the longer the processing time the lower the lignin content. The lowest lignin content in $1 \mathrm{~N} \mathrm{NaOH}$ concentration is $11 \%$ at 20 minutes with a percent decrease reaching $67.65 \%$, lignin at the 25 minute is also $11 \%$ which is the same as the 20 minute this shows that 20 minutes is the optimal time to degrade lignin so that in the 25 minute it cannot degrade lignin again. The lowest lignin content in $2 \mathrm{~N} \mathrm{NaOH}$ concentration is at the 20th minute which is $6 \%$ with a decrease in percentage reaching $82.35 \%$. While the lowest lignin content was at the $3 \mathrm{~N} \mathrm{NaOH}$ concentration which was $9 \%$, at 20 minutes with a percent reduction reaching $73.53 \%$. This proves that the longer the lignin content also decreases and the most optimal time to reduce lignin is 20 minutes. Yang Haiping explained that hemicellulose degradation occurred at $220-315 \mathrm{oC}$, cellulose occurred at $315-400^{\circ} \mathrm{C}$ and lignin occurred at $100-900^{\circ} \mathrm{C}$ [16]. So the 
researcher's hypothesis states that at the 25 minute the temperature in the material reaches above $315^{\circ} \mathrm{C}$ which results in cellulose being degraded along with lignin. The incident was due to the longer exposure to microwaves to the ingredients in the alkaline solution resulted in more degraded lignin. This is related to the effect of heat caused during the time of microwave exposure. The longer the exposure time, the effect of heat generated by electromagnetic waves also increases so that it can degrade bonds in lignin more. This is in accordance with Sumada's opinion which states that temperature and pressure affect the delignification process, namely the greater the temperature and pressure, the faster the processing time [17]. Meanwhile, according to Maharani in his research, it shows that the longer the pretreatment time, the temperature that occurs also rises, this happens because of the heat transfer from the microwave to the material will continue to occur over time [7]

Based on the theory, there are several factors that influence the delignification process, namely the concentration of the cooking solution and the comparison of the cooking solution with the raw material. If the lignin content used is large, the concentration of the cooking solution must also be large. In addition, the smaller the comparison of the cooking solution with the raw material, the degraded lignin will also be smaller. The cooking solution in this process is an alkaline solution $(\mathrm{NaOH})$, where the $\mathrm{OH}^{-}$ion from $\mathrm{NaOH}$ will break the bonds of the basic structure of lignin while the $\mathrm{Na}^{+}$ion will bind with lignin to form sodium phenolate. This phenolic salt is soluble. Dissolved lignin is marked in black in a solution called black liquor [14]. This is in accordance with this research that during the delignification process that is brown candlenut shell powder added with a solution of $\mathrm{NaOH}$ to become black.

The neutralizing filtrate at each residue becomes colorless and clear because the remaining $\mathrm{NaOH}$ solution, phenolic salt and hemicellulose which are still left in the residue are carried away during washing. The residual color from cellulose extraction from processing waste so that it is almost the same that is light brown and different from the initial sample color which is dark brown. According to Coniwanti, the destruction of lignin compounds by $\mathrm{NaOH}$ causes an increase in cellulose levels and can be seen through visual observation of softer color and structure changes [18]. This shows that the components of lignin and hemicellulose which are bound to cellulose in each residue are reduced. At $1 \mathrm{~N} \mathrm{NaOH}$ concentration, it can reduce lignin up to $67.64 \%$. This also occurs at $2 \mathrm{~N}$ concentrations which can reduce lignin reaching $82.35 \%$ and at $3 \mathrm{~N}$ concentrations where the percent decrease in lignin reaches $73.53 \%$. The decrease in lignin occurs along with the large concentration of the cooking solution in this case, namely $\mathrm{NaOH}$. However, at $3 \mathrm{~N}$ concentrations the decrease in lignin is still below $2 \mathrm{~N}$ concentrations so that it is possible that at $3 \mathrm{~N}$ concentrations the resulting temperature is greater and it is possible more than $315^{\circ} \mathrm{C}$ which causes cellulose to degrade with lignin.

So from the various factors that influence the delignification process, it is obtained the most optimal results to reduce lignin in candlenut shell powder, namely the concentration of $\mathrm{NaOH} 2 \mathrm{~N}$ with 20 minutes with a percent decrease reaching $82.53 \%$ which produces $6 \%$ lignin content with $50 \%$ cellulose content. Microwave$\mathrm{NaOH}$ delignification is a type of physics-chemical delignification. The main purpose of the microwave treatment process is to break the complex lignin structure into simpler constituent structures. So that the hydrolysis process and subsequent processes to get bioethanol will be easier to occur. Interaction of the microwave with the material during pre-treatment, will produce a thermal effect which is the response of polar molecules and ions to change the direction of the electric field produced by electromagnetic waves at microwave frequencies. Polar molecules are stretched outside the electromegnetic field, but oscillating (alternating movements) of the electric field from microwave radiation causes polar molecules to vibrate rapidly as a result of lignin which is straightened in the electric field [19].

According to Maharani in his research explained that the longer the pretreatment time, the temperature that occurs also rises, this can be expected that the transfer of heat from the microwave to the material will continue to occur over time. Then, if seen from the higher volume of the solvent, the lower the temperature that occurs, this is allegedly due to heat transfer that occurs when direct microwave irradiation heat of the material then heat spreads to all areas in the container through the solvent and the material itself so that heat transfer occurs convection. Heat transfer to all areas of this material will be faster to all areas if the volume used is the smallest volume. Because the fastest spreading of the temperature is the smallest volume, the high temperature is the smallest volume treatment. [7]

In the microwave there are also several variations in the strength of the power $(\mathrm{P})$. It is estimated that the higher the power used, the greater the microwaves generated and the higher the temperature generated by the microwave so that degradation of lignin can occur more quickly in just a few time. However, the components of lignocellulosic compounds also have a limit or resistance to temperature until they degrade.

Microwave ovens convert electrical energy into heat energy so that this tool can work to heat the food in it. In accordance with the equation of the energy formula:

$$
P=\frac{E}{t}
$$

Power is directly proportional to the amount of energy produced per unit of time. The greater the power used, the higher the energy produced, so that the selection of microwave power in this study is $440 \mathrm{~W}$ which is the standard power of $950 \mathrm{~W}$ maximum power intended so that the heat generated is not too high during the deleignification process so as not to damage the components of the compound that is not desirable like cellulose

\section{CONCLUSIONS}

Based on the analysis results o $\mathrm{NaOH}$ solution, the more lignin is degraded and obtained the $2 \mathrm{~N} \mathrm{NaOH}$ concentration is the most optimal way to degrade lignin. And the longer the 
delignification time, the more lignin is degraded and the most optimal time is 20 minutes to degrade lignin, which is produced by $6 \%$ or it can be said that these conditions can reduce lignin by $82.35 \%$.

\section{ACKNOWLEDGMENT}

The researcher would like to thank the ITN Malang Research Institute and the Directorate of Higher Education for supporting our research and providing an opportunity to qualify for a 2019 external research grant.

\section{REFERENCES}

[1] Lempang, M., Syafii, W. and Pari, G. 2011. Structure and Components of Charcoal and Active Candlenut Charcoal. Center for Research and Development of Forestry Engineering and Processing of Forest Products. Bogor.

[2] Mosier, $\mathrm{N}$ et al. 2005. Features of Promising Technologies for Pretreatment of Lignocellulosic Biomass. Bioresource Technology, 673-686

[3] Wiratmaja, I. G., Kusuma I. G., \& Winajaya I. N. 2011. Making Second Generation Ethanol by Utilizing Euchema Cottonii Seaweed as Raw Material. Journal of Mechanical Engineering Discs, 5 (1): 75-84

[4] Muryanto, M., Y. Sudiyani, and H. Abimanyu. 2016. Optimizing the Process of Palm Oil Bunch NaOH Preparation Process To Become Bioethanol. Indonesia Juornal App. Chem 18 (June): 27-35

[5] Gunam, IB, Wartini, NM, Anggreni, AA, \& Suparyana, PM 2011. Delignification of Sugarcane Bagasse with Sodium Hydroxide Solution Prior to Enzymatic Saccharification Using Rough Cellulase Enzymes from Aspergillus Niger FNU 6018. Indonesian Technology LIPI Press, 34 (Edition of Hydroxide before Enzymatic Wisdom Clarification Using Rough Cellulase Enzymes from Aspergillus Niger FNU 6018. Indonesian Technology LIPI Press, 34 (Edition of the Hydroxide before Enzymatic Wisdom clarification Using Rough Cellulase Enzymes from Aspergillus Niger FNU 6018. 2011 Special): 24--32

[6] Dewi Kartika Rini, Zuhroh Saiyyidah T., Zulaikha Siti, 2018, Delignification of Chandlenut Shell Waste With Alkali Pretreatment Method As An Alternative Fuel Feedstock, International Journal of Mechanical Engineering and Technology (IJMET), Volume 9, Issue 10, ISSN Online 0976-6359

[7] Maharani Dewi, Maya Rosyidin Khulafaur. 2015. Assisted Pretreatment with Microwave Heating to Increase Banana Cellulose Levels in Bioethanol Production. Proceedings of the 2015 National
Innovation and Science Learning Symposium (SNIPS 2015). Bandung

[8] Sari Diana Popi, 2018, Delignification of Corn Cob with the Alkaline Microwave Method, Journal of Agriculture, Volume 2, issue 2

[9] Sun Y., and J. Cheng. 2002. Hydrolysis of lignocellulosic materials for ethanol production: a review. Bioresources Technology, 83, 1-11.

[10] Heradewi. 2007. Isolation of Lignin from Black Lindi Prosers Organosolv Oil Palm Empty Fruit Bunch (TKKS). Bogor: Bogor Agricultural University.

[11] Permatasari Harry Rizka, Gulo Fakhlili, Lesmini Bety. 2011. The Effect of $\mathrm{H} 2 \mathrm{SO} 4$ and $\mathrm{NaOH}$ Concentrations on Delignification of Bamboo Powder (Gigantochloa Apus). Sriwijaya University.

[12] Novia, Khairunnas, Gigih Tejo Purboyo. 2015. The Effect of $\mathrm{NaOH}$ Concentration on Pretreatment and Fermentation Time on Bioethanol Levels of Pineapple Leaves. Vol. 21, No.3. Sriwijaya University

[13] Lestari, Melinda Dwi., Sudarmin. \& Harjono. 2018. Extraction of Cellulose from Processing Waste Using $\mathrm{NaOH}$ Solution as Bioethanol Precursor. Indonesian Journal of Chemical Science

[14] Safaria, Selviza, Nora Idiawati, and Titin Anita Zaharah. 2013. Effectiveness of Cellulase Enzyme Mixtures from Aspergillus Niger and Trichoderma Reesei in Hydrolyzing Coconut Fiber Substrate. Tanjungpura University. Vol. 02 ISSN 2303-1077

[15] Ariani, L., \& Idiawati, N. 2011. Determination of Lignin and Glucose Levels in Organosolv Hydrolysis and Acid Hydrolysis. Journal of Science and Applied Chemistry, 5 (2): 140-1

[16] Yang, Haiping, Rong Yan, Hanping Chen, Dong Ho Lee and Chuguang Zheng. 2007. Characteristics of hemicellulose, cellulose and lignin pyrolysis. Singapore, Science Direct. Fuel 86 (2007) 1781-1788.

[17] Sumada, K., Tamara, P. E., and Alqani, F. 2011. Study of the Isolation Process Proses - Cellulose from the Stem Waste of Manihot Esculenta Crantz Efficient Plants. Industrial Technology Faculty. UPN: Surabaya.

[18] Coniwanti, Pamilia; Laila, Linda; and Alfira, Mardiyah Rizka. 2014. "Making Biodegradable Plastic Films from Corn Starch with Additions

[19] Kodri, Argo, BD and Yulianingsih, R. 2013. Utilization of cellulite from Trichoderma Reseu and Aspergillus Niger as Enzymatic Hydrolysis of Rice Straw with Microwave Pretreatment. J. Tropical Commodities Bioprocess, 1 (1): 36-43. 